\title{
Antonio Arias y Sebastián Martínez, pintores al servicio del duque de Segorbe y Cardona
}

\author{
Manuel García Luque \\ Universidad de Sevilla \\ mgluque@us.es
}

RESUMEN: El trabajo identifica y estudia algunas pinturas que llegaron a Lucena (Córdoba) en el contexto de las empresas artísticas de Luis Ramón Folch de Cardona y Aragón (1608-1670), VII duque de Cardona y VI de Segorbe. Entre ellas se encuentran el cuadro de altar La Virgen de Montserrat con san Juan y santa Marina, firmado por el pintor madrileño Antonio Arias, y un conjunto de diez pinturas que en 1652 se encargaron al pintor giennense Sebastián Martínez Domedel para los retablos colaterales de la iglesia parroquial de San Mateo.

PALABRAS CLAVE: Pintura barroca; Iconografía; Patronazgo nobiliario; Antonio Arias; Sebastián Martínez; Casa de Segorbe y Cardona.

\section{Antonio Arias y Sebastián Martínez, Painters at the Service of the Duke of Segorbe and Cardona}

ABSTRACT: This paper identifies and studies paintings that arrived in Lucena, province of Córdoba, in the context of the artistic patronage of Luis Ramón Folch de Cardona and Aragón (1608-1670), 2nd Duke of Cardona and 6th of Segorbe. These works are the canvas The Virgin of Monserrat with Saint John and Saint Margaret, signed by the painter Antonio Arias, and a set of ten paintings commissioned to the painter Sebastián Martínez Domedel from Jaén in 1652 for two altarpieces for San Matthew's parish church.

KEYWORDS: Spanish Baroque Painting; Iconography; Nobiliary Patronage; Antonio Arias; Sebastián Martínez; House of Segorbe and Cardona.

Recibido: 28 de febrero de 2020 / Aceptado: 7 de junio de 2020.

En 1543, la falta de descendencia masculina provocó que la casa nobiliaria más importante de Cataluña, la de los Folch de Cardona, duques de Cardona, quedara agregada a la casa valenciana de los Aragón, duques de Segorbe, cuyos integrantes se consideraban nobles de sangre o a natura, como descendientes del rey aragonés Fernando I. Idéntico problema sucesorio volvió a plantearse en 1575, cuando ambas casas pasaron a depender de una de las ramas del frondoso árbol de los Fernández de Córdoba, la de los marqueses de Comares, que tenían en la villa de Lucena la cabecera de su estado (Fernández, 2003: 64-65).

La asimilación de las tres casas abrió la puerta a que los intereses de este linaje andaluz se redirigieran hacia Cataluña (Molas, 2006), sobre todo a partir de la tercera década del siglo XVII, cuando Enrique Folch de Cardona y Aragón (15881640), VI duque de Cardona, V de Segorbe y IV marqués de Comares, se transfirió hasta el Principado junto a su esposa Catalina Fernández de Córdoba y sus hijos. A lo largo de este decenio su figura fue ganando peso en el terreno político, lo que culminó con su nombramiento como virrey de Cataluña en 1630. La administración del estado de Comares pasó entonces a depender de su hijo Luis de Aragón (1608-1670), quien, como primogénito, ostentaba ya el título de conde de Prades. Con esta misión, el joven aristócrata regresó a Lucena acompañado de su esposa Mariana de Sandoval, hija del duque de Lerma (Fernández, 2003: 89-96).

Cómo citar este artículo: GARCÍA LUQUE, Manuel, "Antonio Arias y Sebastián Martínez, pintores al servicio del duque de Segorbe y Cardona», Boletín de Arte-UMA, n. ${ }^{\circ}$ 42, Departamento de Historia del Arte, Universidad de Málaga, 2021, pp. 143-154, ISSN: 0211-8483, e-ISSN: 2695-415X, DOI: http://dx.doi.org/10.24310/BoLArte.2021. vi42.8141 

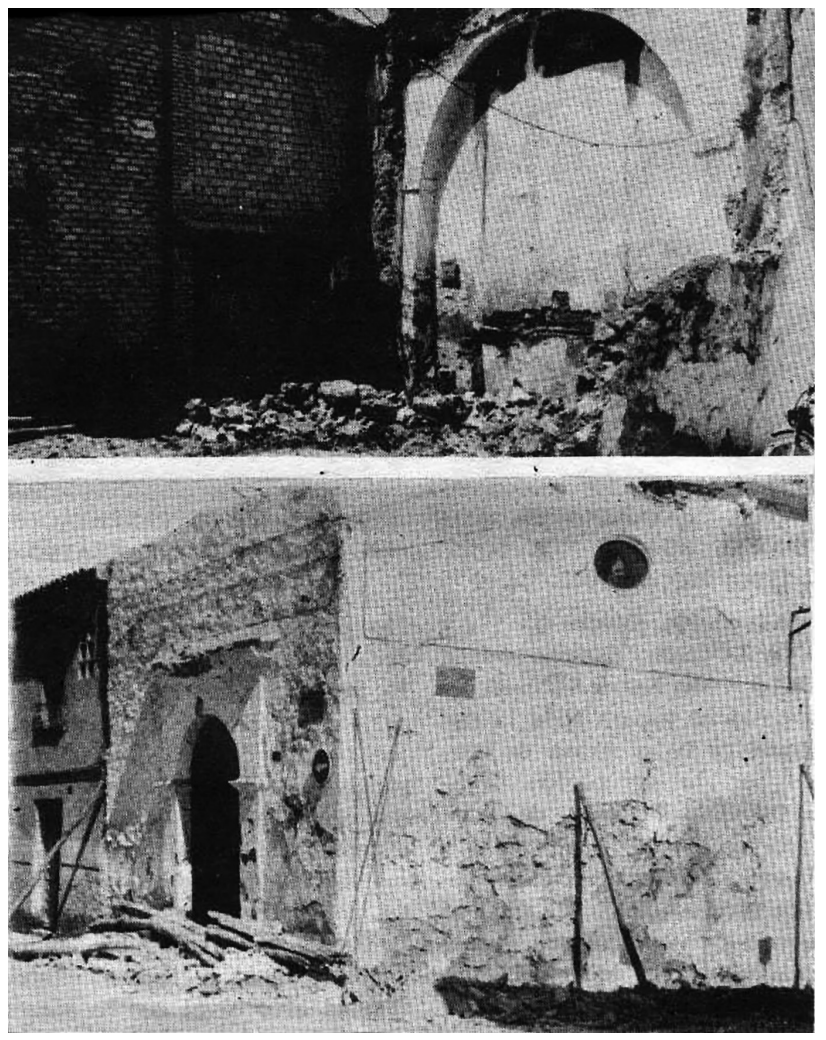

1. Ermita de Nuestra Señora de Monserrat de Lucena, antes y después de su demolición en 1978

En 1640, el conde de Prades sucedió a su padre en todos sus estados como VII duque de Cardona, VI de Segorbe y $\vee$ marqués de Comares, asumiendo el nombre de Luis Ramón Folch de Cardona Fernández de Córdoba y Aragón. Los dramáticos acontecimientos que entonces se vivían en Cataluña, donde acababa de estallar la rebelión, empujaron al nuevo duque a mantener su residencia en Lucena, hasta donde hizo trasladar los documentos evacuados del archivo familiar de Arbeca (Sánchez, 1990: 72). En este periodo, que se prolongó hasta 1655, la presencia del señor en la ciudad supuso un importante elemento de tensión social, que alcanzó su punto álgido en 1647 en una de las conocidas alteraciones andaluzas (Domínguez, 1973: 47). Sin embargo, la estancia de la corte ducal en la urbe también significó un momento especialmente brillante en lo cultural, que se plasmó en diferentes empresas artísticas financiadas por el noble. Este no solo acometió la reforma del castillo medieval para acomodarlo a las exigencias residenciales palatinas
(García, 2013), sino que también ejerció una importante labor de patrocinio artístico sobre diferentes fundaciones religiosas de Lucena, remozando parroquias, construyendo capillas y levantando nuevos altares. En su mayor parte, estos trabajos fueron confiados a pequeños maestros locales, pero, como enseguida se verá, también permitieron involucrar a dos figuras notables de la pintura española del momento: Antonio Arias y Sebastián Martínez Domedel.

\section{La ermita de Nuestra Señora de Monserrat y el cuadro de Antonio Arias}

La instalación de la corte del nuevo duque de Segorbe y Cardona tuvo una inmediata repercusión en Lucena con la erección de una ermita dedicada a Nuestra Señora de Montserrat. Su construcción puede fecharse a comienzos de los años cuarenta del siglo XVII, conociéndose que la primera misa se ofició en enero de 1643 (Ramírez, 1998: 95). El edificio se levantó extramuros, en la confluencia de las calles Juan Blázquez y Collados. A juzgar por una antigua fotografía, tomada poco antes de su demolición en 1978, se trataba de una modesta edificación de albañilería, constituida por una única nave de pequeñas dimensiones, a la que se accedía por una sencilla portada de medio punto [1].

De manera ciertamente sorprendente, parece que la edificación de este templo no partió de una iniciativa del duque, sino de la voluntad de Juan Hurtado de Val y Marina Blázquez. Este matrimonio, envejecido y sin hijos, había decidido al final de sus días invertir su caudal en la construcción de una ermita dedicada a la Virgen, dotándola de su correspondiente capellanía ${ }^{1}$. Se ha pensado que la elección de una advocación con tan poco arraigo en suelo andaluz respondería a unos supuestos orígenes catalanes del fundador, apellidado «Val» (López, 1999: 99), pero los documentos prueban que este personaje había nacido en Lucena en $1575^{2}$. Aunque siempre cabe la posibilidad de que se tratara de una devoción familiar, cuyo origen se remontara alguna generación atrás -ciertamente no sabemos nada del padre del fundador, el enigmático Pedro Val Horquizo-, parece más razonable que fuera el propio duque de Segorbe y Cardona quien, como señor y patrono de todas las iglesias de la ciudad, impusiera esta advocación como requisito para autorizar la fundación. 
Hay que recordar que este noble fue un ferviente devoto de la Virgen de Monserrat, cuya imagen había podido conocer personalmente durante sus años de juventud en Cataluña. El duque poseyó una pintura de esta advocación entre las imágenes de su oratorio (García, 2015: 1.342), también quiso incluirla en el programa iconográfico de la capilla sacramental de San Mateo de Lucena -a la que más abajo nos referiremos-, y en 1669 acabaría donando a la abadía benedictina de Monserrat un lujoso ajuar de plata, constituido por una pareja de ángeles ceriferarios y un par blandones, para que cuatro cirios ardieran perpetuamente ante la venerada talla románica, completando tan generosa dádiva con la institución de una misa diaria cantada (Fors, 1867: 24-25).

Por otra parte, la dedicación de una ermita a la Virgen de la Monserrat también pudo ser vista como una concesión a la pequeña comunidad de catalanes que había recalado en la ciudad en el séquito ducal. Su número es, desde luego, muy difícil de cuantificar, pero su presencia está constatada por casos como el de Pedro Majicassas, que fue botiller del duque en 1633 (García, 2015: 1.338).

La vinculación de la casa ducal con esta ermita lucentina podría arrojar algo de luz sobre el origen de su cuadro de altar, que extrañamente no fue confiado a ningún taller cordobés o andaluz, sino al pintor madrileño Antonio Arias (ca. 1614-1684), entonces vinculado a las obras reales como autor de algunos lienzos para el Salón Dorado del Alcázar³. Puesto que desconocemos cualquier conexión entre los fundadores y la Corte, parece lógico que el encargo llegara a efectuarse por mediación de alguno de los agentes del duque en Madrid.

La pintura llegó a la ermita lucentina en el mes de agosto de 1643, lo que permitió que el 8 de septiembre de aquel año ya se celebrara ante ella la primera fiesta en honor de la Virgen de Montserrat (Ramírez, 1998: 85). Allí permaneció hasta 1965, cuando fue expoliada en oscuras circunstancias (López, 1999: 9), pero puede identificarse sin mucha dificultad con un cuadro que tres años más tarde compró el escultor Frederic Marès en el comercio artístico barcelonés por 250.000 pesetas (Canalda, 2013: 195). Este monumental óleo sobre lienzo $(325$ x $250 \mathrm{~cm})$, firmado y fechado por Arias $^{4}$, representa a Nuestra Señora de Montserrat con san Juan Bautista y santa Marina y se conserva hoy en el Museo Marès de Barcelona [2]. Su identificación con el cuadro pro-

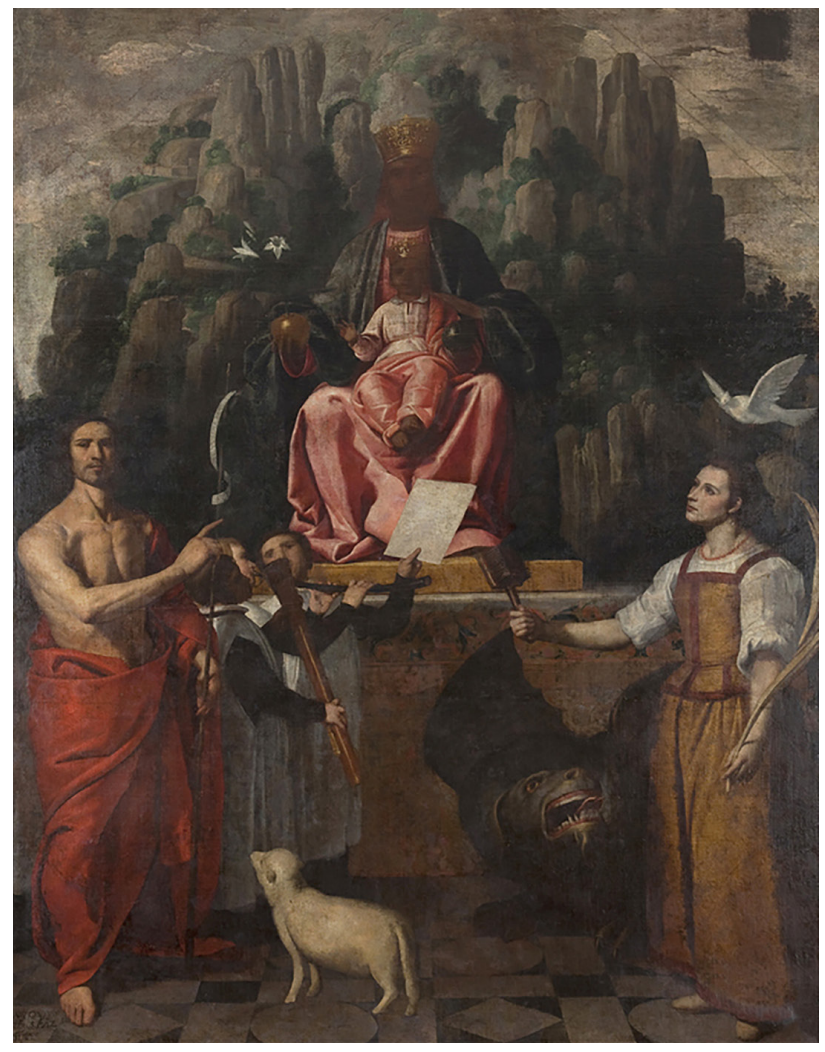

2. Antonio Arias, Nuestra Señora de Monserrat con san Juan y santa Marina, 1643, Museo Marès, Barcelona

cedente de Lucena ofrece pocas dudas, pues se acomoda perfectamente a una descripción dada por el presbítero Fernando Ramírez de Luque a comienzos del siglo XIX: «un lienzo de gran tamaño, ejecutado y firmado por Antonio Arias, año 1643, donde pintó a San Juan Bautista y Santa Marina o Margarita, virgen y mártir, en memoria de los nombres de los fundadores» (1998: 85). Por si ello no fuera suficiente, en esta misma centuria el erudito cordobés Luis María Ramírez y de las Casas-Deza puntualizaba que en la pintura aparecían «tres músicos al parecer monges, uno tocando el bajón, otro la flauta y otro como teniendo un papel de música y cantando» (1986, II: 312).

Arias concibió la pintura en la tradición europea de los grandes cuadros de altar, aunque sin renunciar a algunos recursos característicos de un conocido género de pintura devocional que Pérez Sánchez denominó «trampantojos a lo divino» (1992). Ello se advierte en su interés por crear un «retrato» de la talla románica revestida de ropajes, tal y 
como se podía contemplar en el siglo XVII. El pintor difícilmente tuvo acceso a la imagen original, por lo que debió de inspirarse en alguna estampa o incluso en la réplica escultórica que Manuel Pereira había realizado para el recién fundado monasterio madrileño de Monserrat, donde Felipe IV dio cobijo a los benedictinos castellanos que habían sido expulsados de la abadía catalana (Canalda, 2013: 195). También resulta un expediente habitual en este género de pinturas la inclusión de una mesa de altar, que contribuye a subrayar la presencia física de la imagen dentro del cuadro. La corporeidad casi escultórica de los personajes secundarios, típica del recio lenguaje naturalista de Arias, o el diseño ajedrezado de la solería -que anticipa la que tres años más tarde pintaría en La moneda del César del Prado- también acentúan la nota ilusionista. Con todo, las exigencias iconográficas de la advocación montserratina, en la que no suele faltar la sierra escarpada donde tuvo lugar la aparición mariana, generan una ambientación ciertamente ambigua, como si los personajes estuvieran representados en una capilla dispuesta al aire libre.

\section{Los retablos colaterales de la parroquia de San Mateo y el pintor Sebastián Martínez}

En torno a 1648, el duque Luis Ramón decidió sufragar la construcción de una capilla sacramental a los pies de la parroquia mayor de San Mateo, que fue solemnemente inaugurada dos años más tarde ${ }^{5}$. Pese a su carácter eucarístico, este espacio fue dedicado a la Virgen de Monserrat, que quedó representada a través de una imagen pictórica -ya perdida- que presidía el hueco central del retablo. A la parte alta de este altar se destinaron las pinturas del Cristo de Burgos, San José y San Francisco de Borja -por suerte sí conservadas-, que completaban el rosario de devociones del duque y de su esposa, ya entonces convertida en duquesa de Lerma.

El autor de este sencillo retablo de abolengo escurialense fue Luis Sánchez de la Cruz, un maestro ensamblador asentado en Lucena que trabajó activamente para el duque ${ }^{6}$. Sin embargo, no resulta fácil determinar la autoría de estas pinturas, que tradicionalmente se han venido atribuyendo al pintor local Bernabé Jiménez de Illescas (1608-1678)7 (Bernier, 1987: 105). La documentación exhumada solo prueba que este artista se ocupó del dorado del retablo y de las pinturas murales que exornan la capilla, y, aunque todo hace suponer que los lienzos también sean suyos, la falta de referentes seguros impide asegurarlo con rotundidad ${ }^{8}$.

Sea lllescas o no su autor, parece claro que el comitente no estaba muy convencido de sus dotes como pintor figurativo, como prueba su exclusión de la siguiente empresa artística que patrocinó en la parroquia. El 19 de diciembre de 1651, el duque contrató a Luis Sánchez de la Cruz para que realizara un par de retablos gemelos para los altares colaterales de este templo, con un plazo de ejecución de un año y nueve meses, por valor de 1.000 ducados, excluyendo de este precio la madera de pino que le suministraría la hacienda ducal $^{9}$. Los bancos de jaspe rojo sobre los que asientan los muebles se encargaron al cantero Juan de Morales ${ }^{10}$.

Los nuevos retablos vendrían a cerrar visualmente la cabecera de la iglesia y armonizarían con el extraordinario retablo manierista de la capilla mayor, realizado por Juan Bautista Vázquez el Viejo y Jerónimo Hernández por encargo del III marqués de Comares, Diego Fernández de Córdoba (1524-1601). Sin duda, la existencia de este referente condicionó el diseño de los nuevos retablos, como también lo harían unas imágenes escultóricas preexistentes, titulares de las cofradías de la Asunción y Ánimas, que debían instalarse en las hornacinas centrales. La traza se resolvió acudiendo a un sencillo esquema de banco, un solo cuerpo tetrástilo de columnas toscanas, y un ático rematado en frontón y flanqueado de volutas. Las calles laterales y el ático se destinaron a la exhibición de pinturas, completándose este discurso visual con los correspondientes escudos de armas del comitente, orlados de cartelas de tradición manierista [3].

La prueba de que el duque buscaba costear una obra de empeño la encontramos en el hecho de que en esta ocasión el ciclo pictórico fuera encomendado al giennense Sebastián Martínez Domedel (ca. 1615-1667), uno de los maestros naturalistas más notables del panorama andaluz de mediados del XVII, cuya obra ha sido frecuentemente confundida y parangonada con la de su contemporáneo cordobés Antonio del Castillo (1616-1668) ${ }^{11}$. El pintor se desplazó hasta Lucena el 26 de abril de 1652 para la firma del contrato, por el que se obligaba a realizar diez pinturas por valor de 400 ducados (4.400 reales), de los cuales recibiría 1.000 al inicio. Las medidas de los cuadros vinieron determinadas por los bastidores que le entregó el retablista Sánchez 
de la Cruz, de aproximadamente $180 \times 140 \mathrm{~cm}$ para los dos lienzos del ático, y de $92 \times 75 \mathrm{~cm}$ para los ocho restantes ${ }^{12}$. Es posible que el ajustado plazo de entrega de cinco meses se ampliara a otros cuatro más, según se deduce de las dos cartas de pago que Martínez otorgó en Lucena. La primera, de 1.200 reales, está fechada a 27 de septiembre de 1652, cuando quizás entregó algunas pinturas del lote ${ }^{13}$. La segunda y última se otorgó el 10 de febrero de 1653, constituyendo la fecha extrema para la finalización de los trabajos ${ }^{14}$. Aún habría que esperar una década para que los retablos fueron dorados por el pintor cordobés Francisco de Vargas ${ }^{15}$.

Teniendo en cuenta la amistad que unía a Sebastián Martínez y Juan de Aranda Salazar, maestro mayor de la catedral de Jaén, no sería descabellado pensar que el encargo de estas pinturas se hubiera producido por sugerencia o mediación del arquitecto, quien ya había trabajado para el duque de Segorbe y Cardona suministrándole la traza de un alhorí (García, 2013: 854). Corroboraría esta hipótesis el hecho de que precisamente fuera el ensamblador Luis Sánchez de la Cruz quien alojó a Aranda durante su estancia en Lucena ${ }^{16}$.

En la escritura de concierto se detallan los temas que Martínez debía efigiar. Pese a su aparente heterogeneidad, todos ellos respondían a un elaborado plan iconográfico concebido con un doble propósito. El más evidente era el de ensalzar el linaje de los Segorbe y Cardona mediante el culto a algunas de las devociones más emblemáticas de Cataluña y Valencia, siguiendo una línea propagandística ya trazada en el mencionado retablo de la capilla sacramental. Sin embargo, un nivel más profundo de lectura nos demuestra que tan variopinto repertorio de imágenes no escondía sino un velado homenaje al duque, a su esposa y al último vástago del matrimonio.

Para el retablo del lado del Evangelio, donde se encontraba la imagen titular de la cofradía de la Asunción, se eligieron tres temas de marcado carácter mariano: San Joaquín, santa Ana y la Virgen Niña, la Pentecostés y un retrato de la Virgen de los Desamparados, patrona de Valencia. El cuarto de los lienzos medianos representaría la escena del Tránsito de san José, personaje cuyo culto gozaba de gran arraigo en tierras valencianas, y cuya inclusión en un ciclo de temática mariana estaba plenamente justificada por tratarse de un episodio de la historia sagrada donde también aparece la Virgen María.

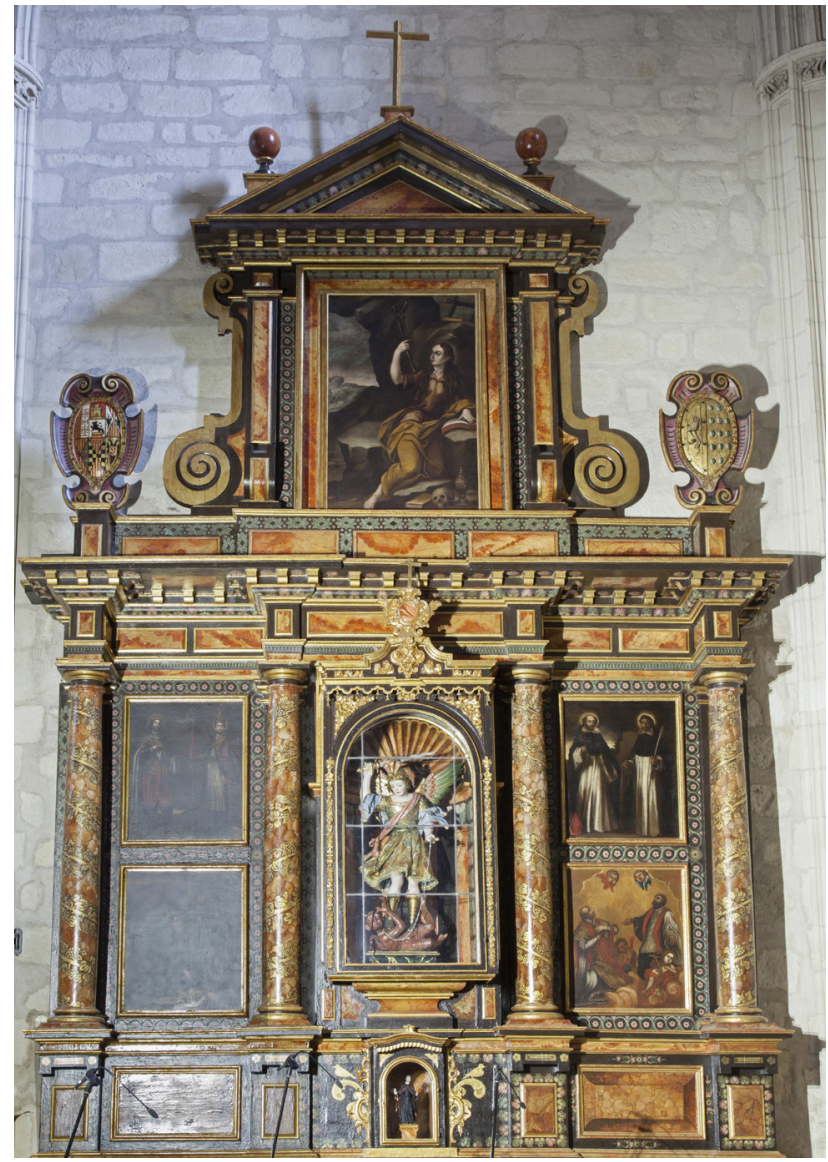

3. Luis Sánchez de la Cruz, Retablo de San Miguel, 1651-1652, Parroquia de San Mateo, Lucena

La lectura iconológica de estos cuatro primeros cuadros permite comprobar que dos de ellos presentan un marcado sentido funerario (Tránsito de san José, como trasunto de la buena muerte) y escatológico (Pentecostés, como venida del Espíritu Santo), lo que los hacía idóneos para un retablo de advocación asuncionista. Sin embargo, es posible que mediante estos temas también se estuviera aludiendo a la duquesa Mariana de Sandoval, quien había fallecido durante la construcción de estos retablos ${ }^{17}$, y cuya figura, desde luego, aparece evocada a través del lienzo de su patrona santa Ana. Esta sospecha se ve reforzada al descubrir la iconografía del lienzo grande del ático: un «san Anbrosio y san Agustín a sus pies» que seguramente aludía al episodio del Bautismo de san Agustín, como lo había representado el grabador Schelte à Bolswert. El cuadro constituiría una clara alusión 


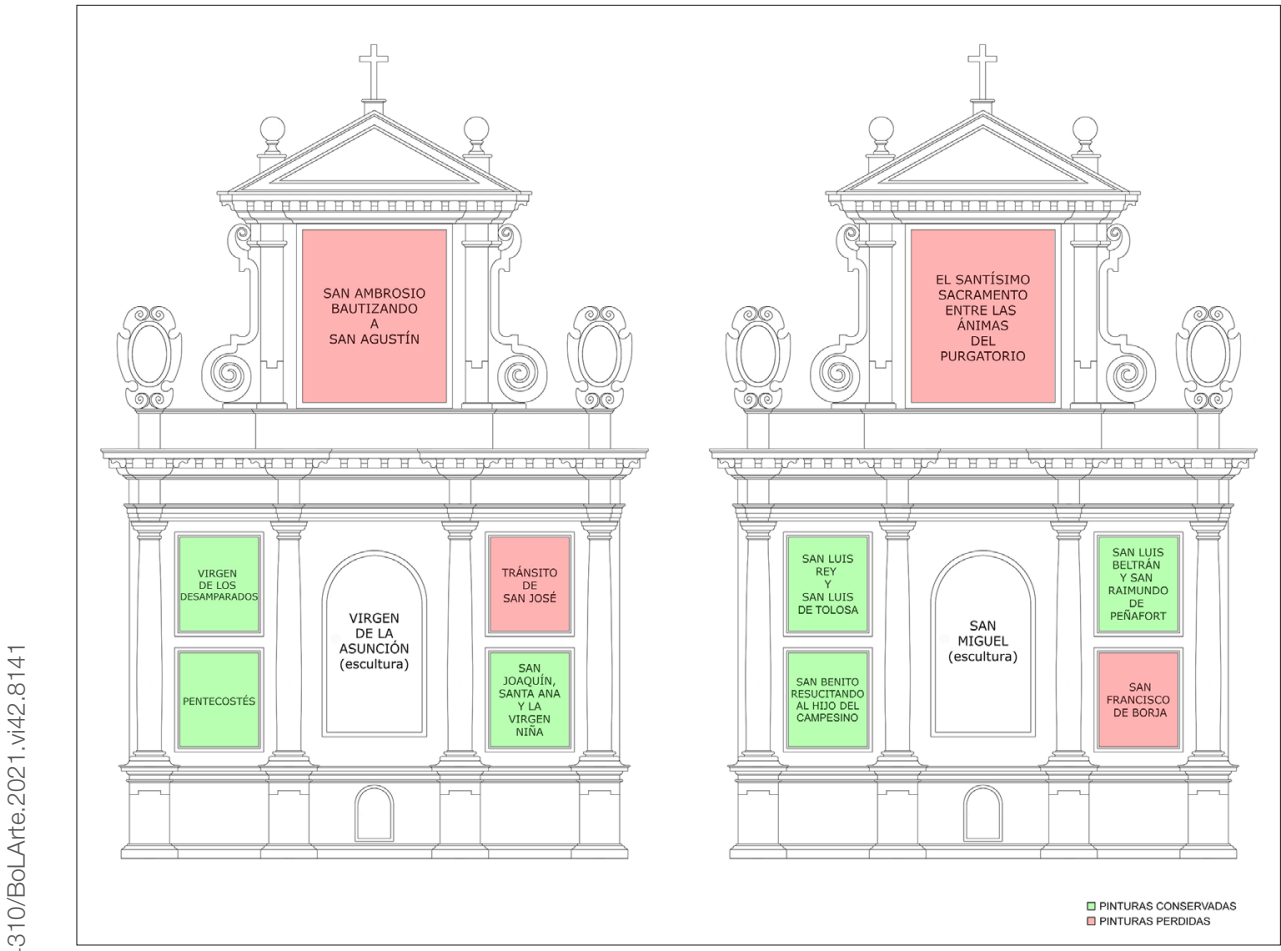

4. Esquema iconográfico de los retablos colaterales de la parroquia de San Mateo de Lucena. Elaboración propia a Ambrosio de Aragón (1650-1659), último de los vástagos que dio a luz Mariana de Sandoval y promesa de sucesión de su casa, al ser el único hijo varón que quedaba vivo.

Si en el retablo de la Asunción se habían reunido los santos protectores de su difunta esposa y de su hijo recién nacido, los del duque se reservarían para el altar del lado de la Epístola, dedicado a San Miguel. Haciendo un juego de palabras con su nombre compuesto, en los registros superiores de las calles laterales se ubicaron los lienzos donde aparecen de forma pareada San Luis rey y san Luis de ToIosa, y San Luis Beltrán y san Raimundo de Peñafort. En los lienzos inferiores se efigió a San Benito y al, entonces beato, Francisco de Borja. El duque de Gandía encajaba plenamente en esta constelación de santos de la corona de Aragón, y su inclusión estaba más que justificada en un contexto de piedad nobiliaria, puesto que tanto los Sandoval como los Aragón estaban lejanamente emparentados con él. Por lo que respecta al fundador de los benedictinos, su presencia puede responder a una concesión hacia al clérigo Benito de Gálvez, quien en 1635 había refundado la cofradía de Ánimas con apoyo del duque (López, 2006: 84), y a quien quizás haya que atribuir el papel de mentor iconográfico de todo el programa. Por otra parte, el episodio escogido -la resurrección del hijo de un campesino ante las puertas de la abadía de Montecasino- resultaba muy apropiado para un altar de ánimas por sus connotaciones funerarias. Este discurso resultaría mucho más explícito en el gran lienzo del ático, lugar para el que se reservó el raro tema del Santísimo Sacramento entre las Ánimas del Purgatorio, que reflejaba la intensa piedad eucarística del duque.

La documentación de este ciclo pictórico, tradicionalmente atribuido a Illescas ${ }^{18}$, viene a respaldar las palabras de Palomino cuando aseguraba que «en Lucena, tengo noticia, que ay algunas pinturas de nuestro Martinez con grande aprobacion de los del Arte» (1724: 362). Desgraciadamente, el aspecto que hoy ofrece este conjunto no puede resultar más decepcionante. A su pésimo estado de conservación hay que sumar la desastrosa restauración que sufrió entre 1789 y 1790, cuando todos los lienzos fueron bajados de sus retablos. En aquel momento, los dos cuadros de mayor tamaño y los dos medianos que representaban el Tránsito de san José y el Beato Francisco de Borja debían encontrarse en tal mal estado que directamente se optó por desecharlos, colocando en su lugar cuatro nuevas 


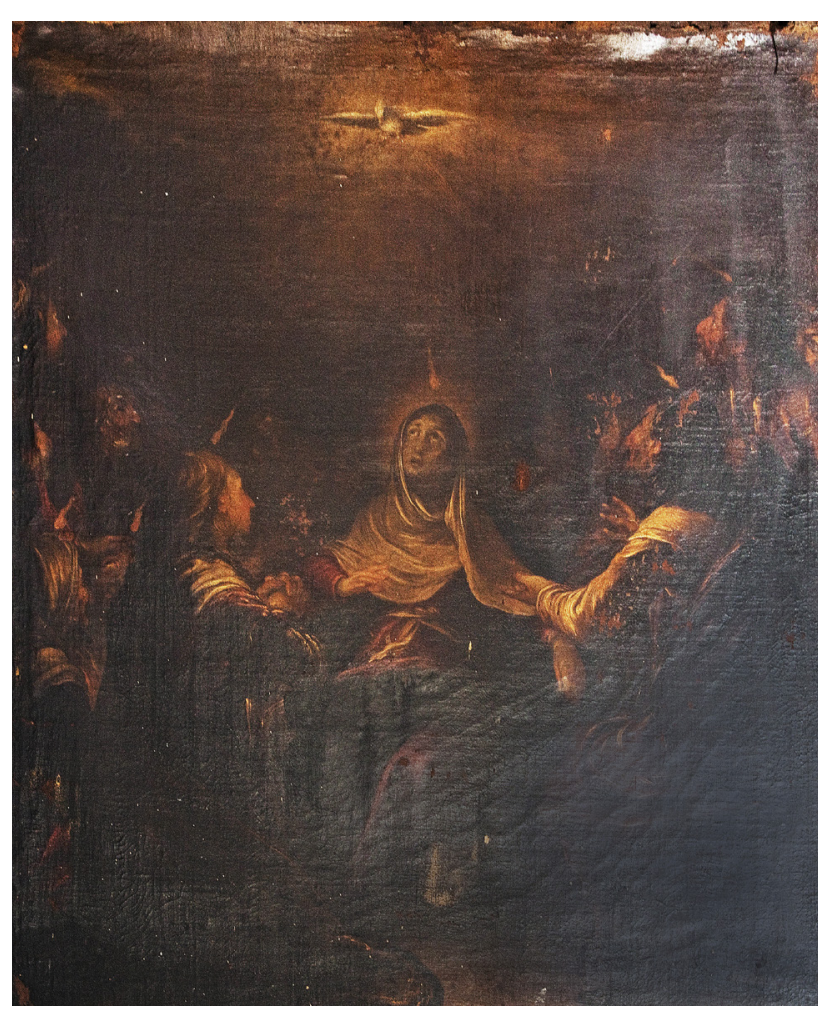

5. Sebastián Martínez, Pentecostés, 1652-1653, Parroquia de San Mateo, Lucena

pinturas de tan mediocre factura que su contemporáneo Ramírez de Luque no vaciló en calificarlas de «mamarrachos» (1998: 143). No sabemos si el artista anónimo ${ }^{19}$ que las realizó reaprovechó los lienzos de Martínez o directamente se valió de nuevas telas, pero lo cierto es que su actuación acabaría rompiendo el sentido iconográfico del conjunto, al efigiar otros asuntos que nada tenían que ver con los originales ${ }^{20}$. Seguramente fue este mismo personaje quien se ocupó de «componer» los seis lienzos de Martínez que volvieron a ser colocados en sus retablos, rehaciendo algunas figuras con torpes repintes ${ }^{21}$.

También debió de ser en torno a esta fecha cuando se añadió un sagrario rococó al retablo de San Miguel y ambos altares fueron jaspeados en vivos colores. En fecha indeterminada volverían a ser jaspeados en blanco, según acredita una fotografía de $1916^{22}$, y luego serían repintados en un tono plano burdeos. Por último, la restauración practicada en el año 2021 sobre el retablo de San Miguel ha recuperado la primera de estas tres repolicromías.

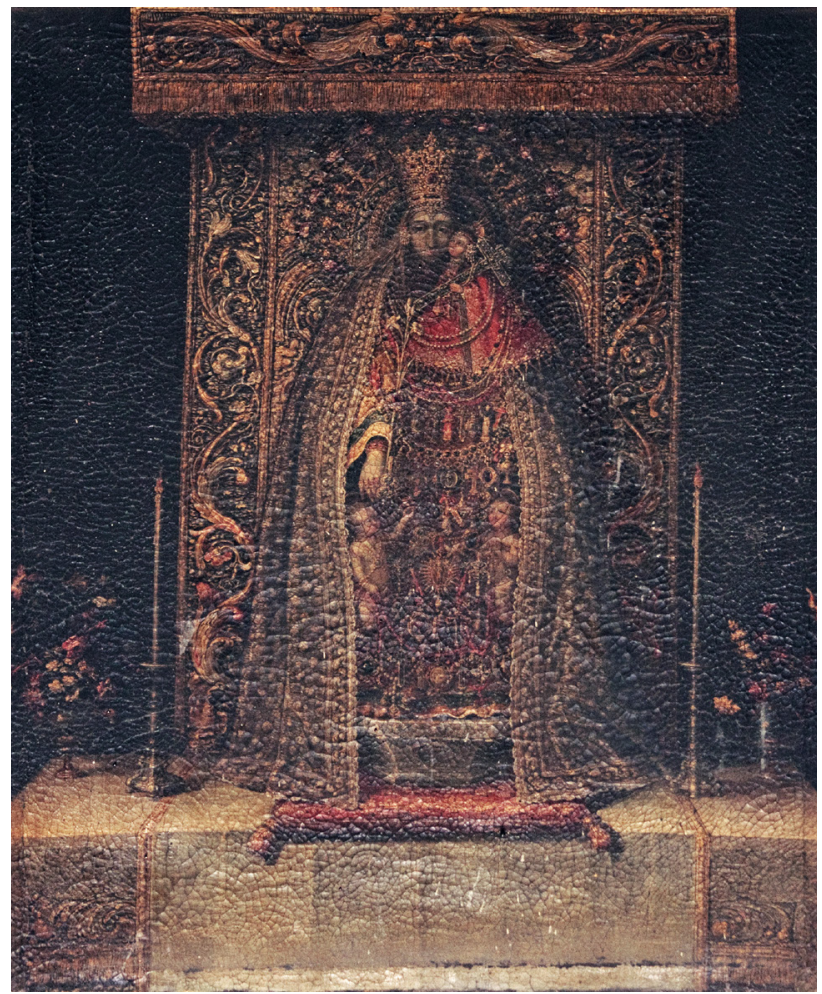

6. Sebastián Martínez, Virgen de los Desamparados, 1652-1653, Parroquia de San Mateo, Lucena. Firmado: «Sebastianus»

De los seis lienzos conservados, el que mejor refleja la personalidad de Sebastián Martínez es el dedicado a la Pentecostés, pues, a pesar de su evidente deterioro, parece libre de repintes [5]. En esta abigarrada composición aparecen algunos de los tipos más característicos del giennense, construidos con su típica pincelada deshecha y filamentosa y ese peculiar estilo «anieblado» que ya ponderaba Palomino (1724: 362). Su habilidad a la hora de plantear los contrastes lumínicos le permite fijar la atención en la figura sorprendida de María, verdadero foco de luz dentro del cuadro; en torno a ella se arremolina todo el colegio apostólico, que contempla atónito la llegada del Espíritu Santo y la aparición de las lenguas de fuego sobre sus cabezas.

Otra de las obras mejor conservadas es la Virgen de los Desamparados, aunque paradójicamente es una de las que menos aporta al conocimiento de la obra de Martínez por tratarse de una pintura devocional [6]. Seguramente fue realizada a partir de algún grabado o pintura suministrado por el comitente, quien poseía un cuadro de este mismo 


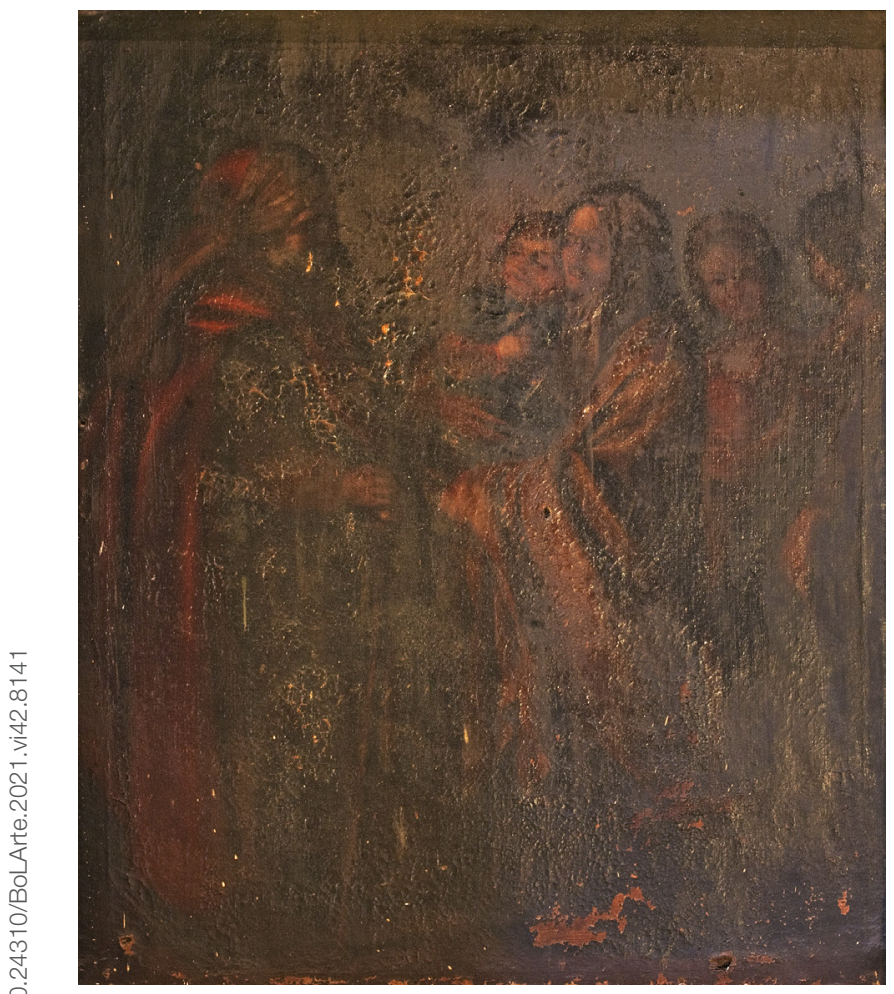

7. Sebastián Martínez, San Joaquín, santa Ana y la Virgen niña, 16521653, Parroquia de San Mateo, Lucena

asunto en su oratorio (García, 2015: 1.342). El pintor representó con suma minuciosidad el aspecto que entonces ofrecía esta imagen gótica en su altar barroco, completamente cubierta de joyas y textiles y cobijando bajo su manto la pareja de niños inocentes que dan nombre a su advocación. Curiosamente, los candeleros que flanquean la imagen son los mismos que aparecen representados en otra pintura firmada por Tomás Yepes en 1644, conservada en el monasterio de las Descalzas Reales de Madrid (Pérez, 1992: 153), aunque aquí la composición se ha enriquecido con los jarrones florales de los extremos, que añaden algún detalle de naturaleza muerta de cierto interés.

Mayor entidad tuvo que ofrecer en su día la pintura de San Joaquín, santa Ana y la Virgen niña, aunque el oscurecimiento de los barnices y las pérdidas de materia pictórica lo hacen hoy prácticamente irreconocible [7]. El estilo de Martínez todavía se adivina en el férreo dibujo de las figuras y el plegado lineal de las telas. A la izquierda de la composición se aprecia la figura de Joaquín, ataviado con la típica indu-

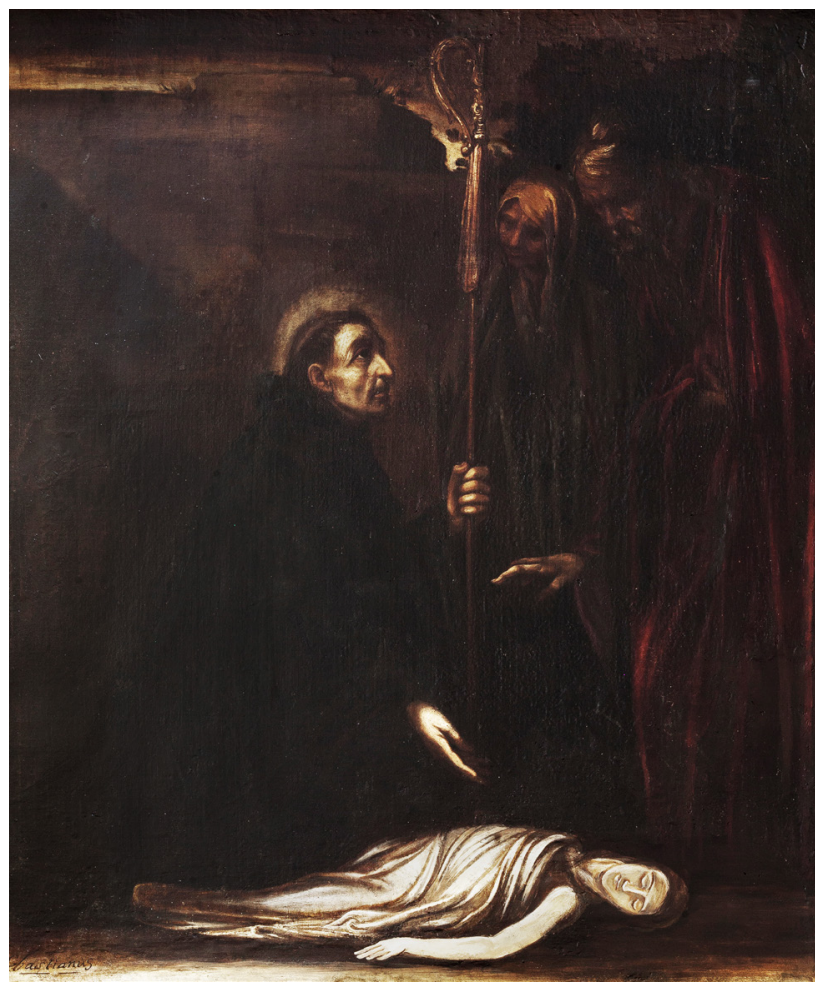

8. Sebastián Martínez y anónimo del XVIII, San Benito resucitando al hijo del campesino, 1652-1653, Parroquia de San Mateo, Lucena. Firmado «Sebastianus»

mentaria orientalizante, mientras que dos figuras femeninas dialogantes asoman por la derecha y la madre de la Virgen se sitúa en el centro, sosteniendo a la niña en sus brazos.

Las tres pinturas del retablo de San Miguel son, sin duda, las más repintadas, y de no ser por la documentación y por las firmas aparecidas en dos de ellas resultaría difícil reconocer la mano de Sebastián Martínez. Para calibrar el alcance de la intervención dieciochesca basta con estudiar detenidamente al cuadro de San Benito resucitando al hijo del campesino [8]. Salta a la vista que las torpes figuras del santo arrodillado y el cadáver fueron totalmente rehechas por el anónimo restaurador, pero no así los personajes del campesino y su mujer, cuyos tipos recuerdan poderosamente a los personajes secundarios que aparecen en la Adoración de los Pastores que perteneció al convento cordobés del Corpus Christi23.

En los lienzos que representan a las parejas de santos patronímicos, los repintes son tan generalizados que su interés ha quedado reducido a los aspectos compositivos e 
iconográficos. Encarados al espectador y tocados con halos de santidad luminiscentes, se disponen de cuerpo entero ante un fondo cobrizo, con la línea del horizonte muy baja, a la manera en que Martínez efigió a San Ignacio de Loyola y San Francisco Javier en los cuadros que pertenecieron a la parroquia de Cabra del Santo Cristo (Jaén) (Navarrete, 2018: 38-41). La pintura dedicada a los santos franciscanos representa a Luis de Francia en su doble condición de rey y caballero cruzado, sosteniendo la reliquia de la corona de espinas traída de Tierra Santa, mientras que su compañero Luis de Tolosa -santo de especiales vinculaciones catalanas, pues transcurrió parte de su vida en Barcelona- aparece caracterizado en su dignidad de obispo, con una corona real a los pies que simboliza su renuncia al trono que le correspondía como primogénito de Carlos II de Nápoles [9].

En cuanto a la pareja de santos dominicos [10], el catalán san Ramón o Raimundo de Peñafort ha sido efigiado con sus atributos habituales: la llave y el voluminoso libro de leyes que sostiene en sus manos, y una mitra a sus pies simbolizando su renuncia a las dignidades episcopales. Frente a esta iconografía convencional, extraña el modo en que fue representado el valenciano Luis Beltrán, sosteniendo un flagelo y una palma, que empuña con la misma fuerza con la que sostiene su atributo martirial la Santa Águeda de la colección Granados.

\section{Conclusiones}

Pese a su expolio y dispersión, las once pinturas analizadas en este trabajo constituyen probablemente los objetos de arte más preciados de cuantos llegaron a Lucena durante la estancia de la corte ducal a mediados del siglo XVII. Su interés trasciende la esfera puramente artística al haber posibilitado, mediante su exposición pública en diferentes templos de la ciudad, el culto a una serie de devociones catalanas y valencianas en un contexto foráneo. Con ello no solo se lograron visibilizar los vínculos de esta rama de los Fernández de Córdoba con sus estados de la corona de Aragón, sino que también se honró a la figura del duque Luis Ramón y a su parentela, poniendo de relieve el importante papel que la imagen religiosa podía desempeñar al servicio de los intereses representativos del linaje.

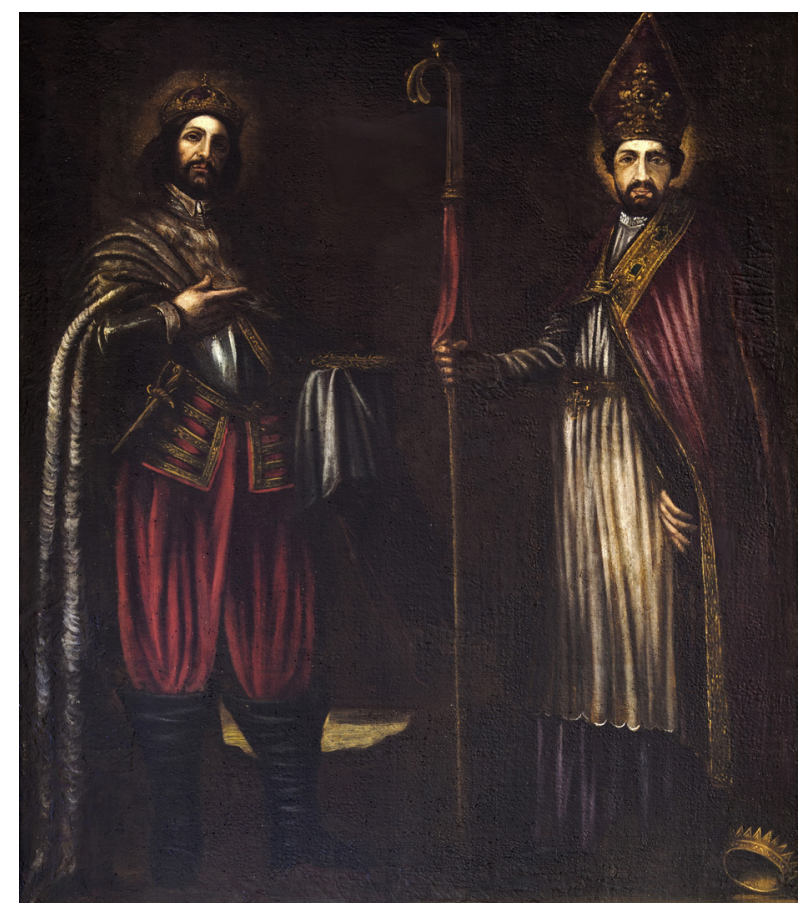

9. Sebastián Martínez y anónimo del XVIII, San Luis rey y san Luis de Tolosa, 1652-1653, Parroquia de San Mateo, Lucena

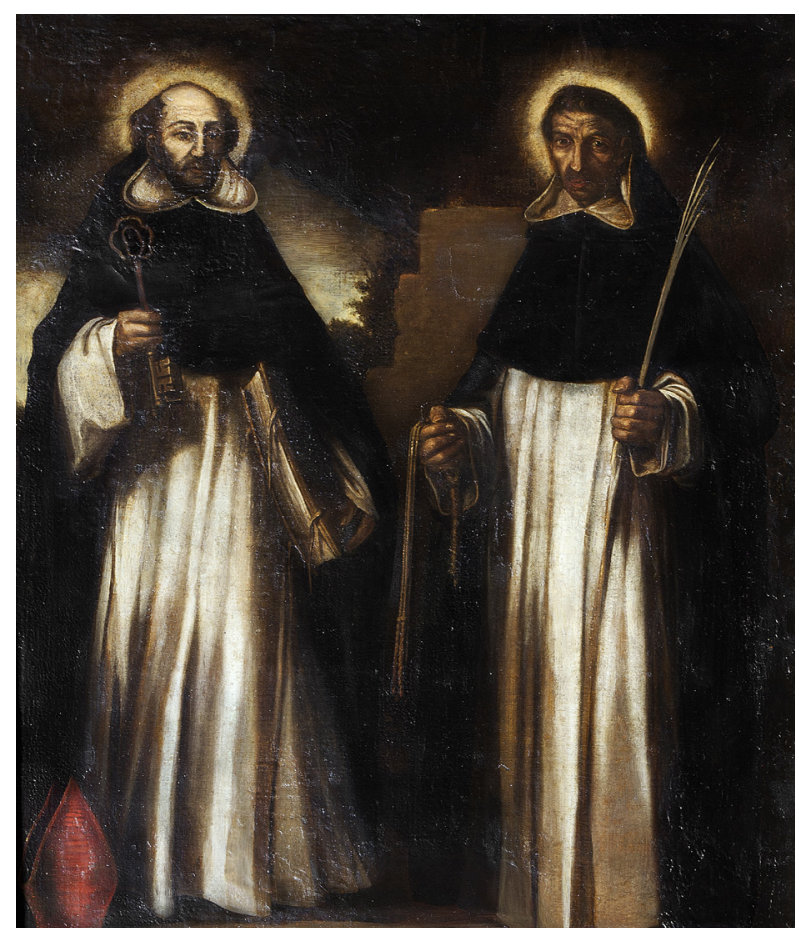

10. Sebastián Martínez y anónimo del XVIII, San Luis Beltrán y san Raimundo de Peñafort, 1652-1653, Parroquia de San Mateo, Lucena 
Hasta el momento no ha sido posible aclarar las circunstancias en que se produjeron ambos encargos, aunque todo apunta a que el cuadro de Antonio Arias se adquirió por mediación de algún agente ducal en la corte de Madrid, en tanto que Juan de Aranda Salazar pudo ser el contacto giennense que facilitó el encargo a Sebastián Martínez del ciclo de los retablos laterales de San Mateo. Esta serie debió de representar un hito importante en la trayectoria del pintor, pues hasta la fecha constituye su mayor conjunto de obras documentadas, y es probable que le abriera la puerta a nuevos encargos para la alta nobleza. Así, no parece casual que en octubre de 1653 -algunos meses después de concluir los cuadros de Lucena- Martínez acudiera a la llamada de Rodrigo Ponce de León (1602-1658), IV duque de Arcos y a la sazón cuñado del duque de Segorbe, para realizar el gran cuadro de altar que presidió la iglesia del convento capuchino de Marchena (Ravé, 2004: 288; 2019: 186-187).

De igual modo, cabría preguntarse si Segorbe volvió a requerir los servicios de ambos pintores en algún otro momento, sobre todo tras su posterior traslado a Madrid. Des- de luego, da que pensar la reciente localización en el Museo del Monasterio de Poblet de un cuadro de San Antonio con el Niño firmado por Sebastián Martínez (Mantas y Amorós, 2019) ${ }^{24}$, pues precisamente este monasterio cisterciense se encontraba bajo el patronato del noble cordobés, quien costeó importantes obras de mejora en la iglesia, a la que dotó de portada, reja para el presbiterio y nuevas cámaras sepulcrales para adecentar el panteón ducal donde reposaban los restos mortales de sus antepasados, simbólicamente situados a escasos metros de las tumbas de los reyes de Aragón (Martinell, 1950: 71-72).

Si Martínez volvió a cruzarse con el duque de Segorbe durante su aventura cortesana es una incógnita que por el momento resulta imposible despejar, aunque de lo que no cabe duda es que el pintor acabaría poniéndose al servicio de otro aristócrata, don Diego Gómez de Sandoval (Agulló, 1978: 94-95), quien curiosamente se había convertido en un firme rival de Segorbe tras haber logrado arrebatar el título de duque de Lerma a su primogénito, el malogrado Ambrosio de Aragón (Fernández, 2003: 97).

\section{Notas}

1 Codicilo de Juan Hurtado Val y Marina Blázquez (12-III-1643), Archivo Histórico Provincial de Córdoba (AHP, Córdoba), Protocolos Notariales de Lucena (PNL), Leg. 3133P, ff. 168r-169v.

2 Ambos eran oriundos de Lucena, donde se desposaron el 2-V-1597. Archivo Parroquial de San Mateo, Lucena (APSM, Lucena), Desposorios 3, f. 145r. Juan era hijo de Pedro Val Horquizo y Quiteria Martín y fue bautizado el 8-IX-1575. APSM, Lucena, Bautismos 8, f. 289v. Marina era hija de Sebastián Jiménez Rollón y Marina Blázquez y, aunque no se ha localizado su fe de bautismo, es probable que naciera en Lucena en la década de 1570 como lo hicieron sus hermanos Miguel y Sebastián. APSM, Lucena, Bautismos 8, f. $225 \mathrm{r}$ y Bautismos 9, f. 120v.

3 Sobre Arias, véanse Angulo y Pérez, 1983: 12-30, y Pérez, 2010: 250-251.

4 En el ángulo inferior izquierdo: «ANTONIVs./ ARIAS FAZ/ 164[3]». N. inventario MFM S-157. Fue primeramente estudiado por Angulo y Pérez, 1983: 30.

5 Su construcción corrió a cargo del maestro Andrés Martín Moreno. Bernier, 1987: 81; López, 2006: 94-95.

6 AHP, Córdoba, PNL, Leg. 2001P, ro 1649, f. 298r (carta de pago, 22-VII-1649) y f. 401r (carta final de pago, 8-X-1649).

7 Sobre este pintor, véase García, 2011-2012.

8 AHP, Córdoba, PNL, Leg. 2001P, ro 1649, f. 271r-v (contrato de 22-VI-1649), y ro 1650, ff. 192r y 222r (cartas de pago de 24-V-1650 y 10-VII-1650).

9 AHP, Córdoba, PNL, Leg. 3087P, s/f.

10 AHP, Córdoba, PNL, Leg. 2001P, ro 1650, f. 361r-v (contrato de 21-XII-1650) y Leg. 3087P, s/f (carta de pago de 21-XII-1651). Aunque se ajustaron en 3.000 reales, finalmente ascendieron a 4.000 .

11 Además de la tesis doctoral de Rafael Mantas (2017), véanse Pérez, 2010: 275-276; Palencia, 2011; Navarrete, 2018 ; y Galera y Serrano, 2018.

12 AHPCO, PNL, Leg. 2439P, f. 190r-V.

13 AHP, Córdoba, PNL, Leg. 2439P, f. 324r.

14 AHP, Córdoba, PNL, Leg. 2369P, f. 38r.

15 AHP, Córdoba, PNL, Leg. 3135P, ff. 275r-276v (contrato de 2-V-1664), y Leg. 2553, f. 137r-v (carta de pago de 11-V-1665). El dorado se ajustó en 15.750 reales. La noticia de su autoría ya había sido dada en Bernier, 1987: 102; García, 2015: 1.336, n. 19.

16 Archivo Ducal de Medinaceli, Sevilla (ADM, Sevilla), Segorbe, Leg. 24, t. I, f. 575v. En 1670 Sánchez de la Cruz declaraba que «la plantta del dicho alhori se hizo en las cassas destte testtigo por Juan de Aranda Salazar, maestro mayor de obras de Jaen, y habra que se hizo dicha obra mas de veinte años».

17 Falleció el 12-III-1651. Fernández, 2003: 93.

18 El primero en atribuírselas fue el presbítero Ramírez de Luque (1998: 143), a quien ha seguido toda la bibliografía posterior. Bernier, 1987: 102; Villar, 1995: 595; López, 2006. 
19 Acaso pudo ser Francisco José López o Pedro Casasola, pintores que por aquellos años acometieron otros trabajos en la parroquia.

20 APSM, Lucena, Fábrica, 1789, gastos menores: «Ydem paguè veinte rreales por clabar dos cruces que estàn en los remates de los dos retablos de los altares de Nuestra Señora de Agosto y de señor San Miguel y poner quatro lienzos en dichos retablos". Los nuevos cuadros representan los temas de San Sebastián, la Magdalena, San Pedro, y San Ignacio y san Francisco Javier, este último copia de una estampa de Benoît Thiboust sobre composición de Giuseppe Orazi.

21 APSM, Lucena, Fábrica, 1790, gastos menores: «Ydem pague veinte reales por componer unos lienzos de los retablos de los dos coraterales de la yglesia mayor. / Ydem pague diez reales por poner dichos lienzos».

22 Fue publicada en el n. ${ }^{\circ} 138$ de la Revista Aracelitana, p. 85.

23 Forma parte de un ciclo de cuatro pinturas, tres de las cuales se conservan hoy en el convento cordobés de Santa María de Gracia. Su ejecución se viene situando últimamente en torno a 1655-1660. Navarrete, 2018: 37.

24 Es cierto que la pintura ingresó en el cenobio durante la posguerra, tal vez como depósito de la Junta de Incautación, aunque nada impide que formara parte de la dotación primitiva del monasterio, cuyos bienes habían sido dispersados con la exclaustración.

\section{Bibliografía}

AGULLÓ COBO, Mercedes (1978), Noticias sobre pintores madrileños de los siglos XVI al XVII, Universidad de Granada, Granada.

ANGULO Iĩ̃IGUEZ, Diego y PÉREZ SÁNCHEZ, Alfonso E. (1983), Historia de la pintura española: escuela madrileña del segundo tercio del siglo XVII, CSIC, Madrid.

BERNIER LUQUE, Juan et al. (1987), Catálogo Artístico y Monumental de la provincia de Córdoba, t. V, Diputación, Córdoba.

CANALDA I LLOBET, Silvia (2013), «Retratos y réplicas de las santas imágenes en época moderna. El caso de Nuestra Señora de Montserrat», en Copia e invención. Modelos, réplicas, series y citas en la escultura europea (comunicaciones), Museo Nacional de Escultura, Valladolid, pp. 187-201.

DOMÍNGUEZ ORTIZ, Antonio (1973), Alteraciones andaluzas, Narcea, Madrid.

FERNÁNDEZ DE BETHÉNCOURT, Francisco (2003), Historia genealógica y heráldica de la Monarquía Española, Casa Real y Grandes de España, t. IX, Fabiola de Publicaciones, Sevilla.

FORS DE CASAMAYOR, Francisco de Paula (1867), La estrella del Monserrat, Viuda é Hijos de D. J. Cuesta, Madrid.

GALERA ANDREU, Pedro Antonio y SERRANO ESTRELLA, Felipe (2018) (coords.), Sebastianus. Pintor de Jaén: Sebastián Martínez Domedel (Jaén, 1615-Madrid, 1667), Instituto de Estudios Giennenses, Jaén.

GARCÍA LUQUE, Manuel (2011-2012), «A propósito de un agente de Pedro de Mena en Lucena: el pintor Bernabé Ximénez de Illescas», Boletín de Arte, n. ${ }^{\circ} 32-33$, pp. 281-309.

GARCÍA LUQUE, Manuel (2013), «Un palacio para el duque: don Luis de Aragón y la reforma del castillo de Lucena (1649-1654)», en MíNGUEZ CORNELLES, Víctor (coord.), Las artes y la arquitectura del poder, Universidad Jaume I, Castellón, pp. 843-858.

GARCÍA LUQUE, Manuel (2015), «Lujo, ostentación y poder: Ios palacios madrileño y lucentino de don Luis de Aragón, VII duque de Cardona, a través de sus inventarios», en IGLESIAS RODRíGUEZ, Juan José, PÉREZ GARCÍA, Rafael M., FERNÁNDEZ CHAVES, Manuel F. (eds.), Comercio y cultura en la Edad Moderna, Universidad de Sevilla, Sevilla, pp. 1.331-1.349.

LÓPEZ SALAMANCA, Francisco (1999), "La capilla del Santísimo Cristo del Amor y de Nuestra Señora de la Paz y la devoción a la Virgen de Monserrat», Campanitas, s/n, pp. 8-10.

LÓPEZ SALAMANCA, Francisco (2006), La parroquia de San Mateo, Ayuntamiento de Lucena, Lucena.

MANTAS FERNÁNDEZ, Rafael (2017), Sebastián Martínez Domedel. Un pintor giennense del seiscientos, tesis doctoral, Universidad de Jaén.

MANTAS FERNÁNDEZ, Rafael y AMORÓS I ALBAREDA, Damiá (2019), «Un San Antonio de Padua con el Niño inédito de Sebastián Martínez Domedel en el museo del Monasterio de Poblet», Atrio, n. ${ }^{\circ}$ 25, pp. 44-57.

MARTINELL, César (1950), "La casa de Cardona y sus obras en Poblet», en Estudios históricos y documentos de los Archivos de ProtocoIos, vol. II, Colegio Notarial, Barcelona, pp. 53-109.

MOLAS RIBALTA, Pere (2006), «Los Folch de Cardona y Andalucía», en Estudios de historia moderna: homenaje a la doctora María Isabel Pérez de Colosía Rodríguez, Universidad de Málaga, Málaga, pp. 343-351. 
NAVARRETE PRIETO, Benito (2018), «Sebastián Martínez Domedel en el contexto de la pintura barroca española», en GALERA ANDREU, Pedro Antonio y SERRANO ESTRELLA, Felipe (coords.), Sebastianus. Pintor de Jaén: Sebastián Martínez Domedel (Jaén, 1615-Madrid, 1667), Instituto de Estudios Giennenses, Jaén, pp. 17-58.

PALENCIA CEREZO, José María (2011), «Sebastián Martínez, el gran desconocido», Ars Magazine, n. 10, pp. 102-114.

PALOMINO DE CASTRO Y VELASCO, Antonio (1724), El parnaso español pintoresco y laureado. Tomo tercero con las vidas de los pintores, y estatuarios eminentes españoles..., [s.n.], Madrid.

PÉREZ SÁNCHEZ, Alfonso E. (1992), «Trampantojos “a lo divino”», Lecturas de Historia del Arte, vol. III, pp. 135-155.

PÉREZ SÁNCHEZ, Alfonso E. (2010), Pintura barroca en España, 1600-1750 (ed. de Benito Navarrete Prieto), Cátedra, Madrid.

RAMÍREZ DE LUQUE, Fernando (1790-1808/1998), Tardes divertidas y bien empleadas por dos amigos en tratar de la verdadera historia de su patria Lucena, Tenllado, Lucena.

RAMíREZ Y DE LAS CASAS-DEZA, Luis María (1986), Corografía histórico-estadística de la Provincia y Obispado de Córdoba (ed. de A. López Ontiveros), Caja de Ahorros de Córdoba, Córdoba.

RAVÉ PRIETO, Juan Luis (2004), «El convento de capuchinos de Marchena», en PELÁEZ DEL ROSAL, Manuel (dir.), El Franciscanismo en Andalucía: conferencias del IX curso de verano Los Capuchinos y la Divina Pastora, Cajasur, Córdoba, pp. 283-296.

RAVÉ PRIETO, Juan Luis (2019), La villa ducal de Marchena, Diputación, Sevilla.

SÁNCHEZ GONZÁLEZ, Antonio (1990), Documentación de la Casa de Medinaceli: el Archivo General de los Duques de Segorbe y Cardona, Dirección de Archivos Estatales, Madrid.

VILLAR MOVELLÁN, Alberto (dir.) (1995), Guía Artística de la provincia de Córdoba, Universidad de Córdoba, Córdoba. 